\title{
Plastics as an Educational Resource for Sustainable Development: A Case Study in Ghana
}

\author{
José-Luis Parejo ${ }^{1, *(\mathbb{C}, \text {, María-O Corton-Heras }}{ }^{2}$, Alba Nieto-Blanco ${ }^{3}$ and Cristina Segovia-Barberan ${ }^{4}$ \\ 1 Department of Pedagogy, Segovia Faculty of Education, University of Valladolid, Plaza de la Universidad, 1, \\ 40005 Segovia, Spain \\ 2 Department of Didactics of Musical Expression, Segovia Faculty of Education, University of Valladolid, \\ Plaza de la Universidad, 1, 40005 Segovia, Spain; mariao.corton@uva.es \\ 3 CEIP “Andrés Segovia”, Circunvalación, 10, Torrejón de Ardoz, 28430 Madrid, Spain; \\ alba.nietoblanco@educa.madrid.org \\ 4 "Montessori" School-British Education, Los Fresnos, Calle de Navacerrada, 13, 28430 Madrid, Spain; \\ cristina.segovia.barberan@gmail.com \\ * Correspondence: joseluis.parejo@uva.es; Tel.: +34-921112387
}

check for updates

Citation: Parejo, J.-L.; Corton-Heras, M.-O; Nieto-Blanco, A.;

Segovia-Barberan, C. Plastics as an Educational Resource for Sustainable Development: A Case Study in Ghana. Sustainability 2021, 13, 6727. https://doi.org/10.3390/su13126727

Academic Editor: Alison Greig

Received: 15 February 2021

Accepted: 10 June 2021

Published: 14 June 2021

Publisher's Note: MDPI stays neutral with regard to jurisdictional claims in published maps and institutional affiliations.

Copyright: (c) 2021 by the authors. Licensee MDPI, Basel, Switzerland. This article is an open access article distributed under the terms and conditions of the Creative Commons Attribution (CC BY) license (https:// creativecommons.org/licenses/by/ $4.0 /)$.

\begin{abstract}
The world is going through a climate crisis that is severely impacting the environment and the well-being of the population. The increased consumption of plastics, especially in developing countries, is generating an exponential rise in plastic waste. This article introduces a qualitative investigation in the form of a case study, with data derived from an educational project focused on plastics as a vehicle for environmental education. This project was implemented with a group of 50 children from a Ghanaian school. Our results reveal that the students acquired a high level of knowledge of plastic and its properties, made possible by an active, globalizing, experimental methodology. This knowledge was later reinforced through the fabrication of materials for learning and play made of recycled plastic waste. Through this project, the participating students practiced critical and democratic global citizenship aimed at creating a sustainable world through an ecological perspective.
\end{abstract}

Keywords: plastics; teaching methods; science experiments; recycling; student projects; conservation (environment); case study

\section{Introduction}

The climate crisis is a global challenge that has been widely studied in recent years. The entire world has spoken out about the urgency of taking action and committing to decisions that can make our planet more sustainable, more habitable, and less prone to environmental disasters. One of the most important issues of the climate crisis is that of plastics, which notoriously and unjustly flood the Global South. This article presents research derived from an environmental education project in a public school in northwestern Ghana, in which global citizenship is an important part of Early Childhood Education. The project closely follows the 2030 Sustainable Development Agenda (SDA), which sets a roadmap for all citizens and organisations to improve-or rather, to save-the world we live in. The purpose of the project was to develop in the students a critical awareness of the impact of plastics on their lives and environment, highlighting the urgency of education for sustainable development.

In Ghana, like many other countries in Africa, Asia, and South America, plastics are a major problem. Their overabundance and the lack of waste management policies $[1,2]$ have led to the country being plagued by an overwhelming amount of plastics. With nowhere to dispose of them, these plastics are dumped on the ground or burned-with all the environmental damage that this entails [3]. Activities in Ghana not only create environmental problems but also reinforce the notion of a wasteful society. To reverse 
this situation, the commitment of the entire population is required alongside effective environmental management. Sustainable Solid Waste Management is a critical issue for a developing country like Ghana, especially for the general welfare of its population [4]. According to Our World in Data [5] and Jambeck et al. [6], 81\% of plastic waste in Ghana is badly managed. Despite the environmental implications, the recycling of plastic products is an industry that could potentially improve the country's economy. Plastic waste is being reused mainly as a raw material for house building and the oil industry [7]. However, the recovery and recycling of plastic waste still have a long way to go; they need to be institutionalized, regulated, and properly integrated into national policies. In addition, environmental education for the entire nation needs to be fostered and local people need to be included in studies, projects, and research [8]. Another policy that could reduce the rate of environmental pollution in Ghana would be a system of taxes to compensate for excess plastic production and consumption [9].

Education for the climate crisis is not effective if it is theoretical only [10]. Therefore, implementing environmental education by simply adding more content to the curriculum may not be the best solution. It is necessary to promote commitment based on active, cooperative, analytical, and critical learning, through projects that invite students to put their knowledge and reflection into practice. Implementing environmental education on climate change through citizen participation will allow for the design of alternative futures that not only seek to solve these problems, but to stop generating them altogether [11]. We believe the first challenge lies in making children feel part of the problem of climate change, to acquire a personal commitment from a deep understanding of the context, and to understand the valuable contributions that can be made as a collective, alongside peers and other local actors. For decades, the scientific community has been warning about the urgency of dealing with climate change. In this context, it is important to be aware of the consequences of poor plastic waste management in the Global South. In this research, environmental awareness and social awareness are addressed together, making the impact of actions tangible and relying on education for a more sustainable world. One of the strong points of this research is its approach to plastics from a new perspective. Raising awareness about the harms of plastic in a community that lives immersed in it is a delicate task and a challenge that cannot be postponed, hence the importance of focusing the entire research process through a critical and transformative perspective for the improvement of Ghanaian society.

\section{Materials and Methods}

\subsection{Research Design}

This study used the qualitative paradigm to raise awareness in students in a public school's Early Childhood Education classroom in Ghana regarding the effects of plastic waste on their community and country. Based on this general objective, we intended to observe the degree of awareness and knowledge of the children regarding the environmental consequences of the use of single-use plastics. We also intended to identify new ways to reuse plastic.

\subsection{Methods, Techniques, and Data Collection Instruments}

This research was based on the qualitative paradigm - it is framed in precise descriptions and theories that allow for patterns to emerge from the collected data [12]. We have chosen the format of a case study to present the results of this teaching project on education for sustainable development in Ghana. A case study examines the particularity and complexity of a specific case. It is not a methodological choice but a choice about the case to be studied. A case study is an investigation into a specific problem within its context. Thus, a case is not intended to be a representation of the world, but the concrete reality of a specific situation, understood in depth, with its themes and patterns of complexity [13-15]. The data collection instruments used in this research were student-produced material (such as artistic creations and toys made from natural materials and plastic), participant observation 
(recorded in a table of observations), and an interview of a support teacher, reinforced by other instruments, such as the teacher's class journal and audio-visual resources comprising photographs and videos (valuable resources for the analysis and reconstruction of the reality of the case study, as we have several audio-visual perspectives of the educational project). The study was done with a group of 50 children with a great diversity in age, developmental rhythms, and interests. The project was developed in the public school "Wulugu Project" located in Larabanga, a village in northwest Ghana. Most of Larabanga's population is Muslim, and the village is home to the oldest mosque in Ghana. It is located near Mole National Park, Ghana's largest wildlife refuge.

This project, especially aimed at children's education, was intended to raise awareness about the excessive production and consumption of plastic. One of the best ways to collect information was to program and implement an educational proposal for education on sustainable development that would address the climate emergency and, particularly, the harmful effects of single-use plastics in Ghana. This proposal was carried out as a project with different phases (presentation, experimentation, and evaluation), as can be seen in Figure 1, and with a progressive design of around 30 activities, as can be seen in Figure 2.

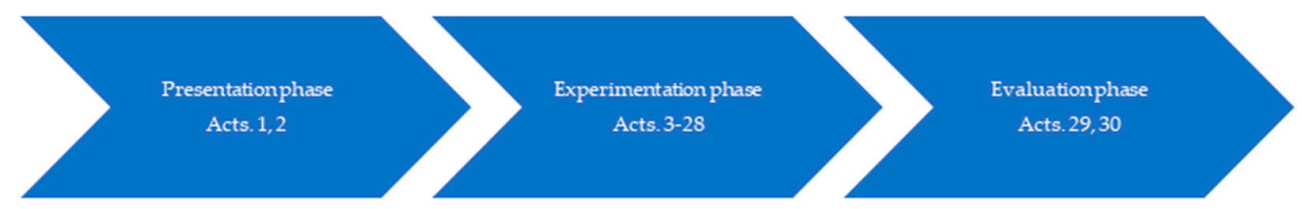

Figure 1. Phases of the project.

The presentation phase helped introduce the subject in a meaningful way, identified what the students knew about it, what motivated them, and what they wanted to learn, and made their thoughts visible [16]. The next stage, experimentation, was key, as it was here that almost the entire educational proposal was developed. The activities were designed openly and flexibly and were organised according to the students' learning needs. Finally, the evaluation phase helped us assess the achievement of the project's goals. During the development of the project, evidence of the learning process was collected through the aforementioned techniques and instruments of evaluation.

The use of multiple data collection techniques guarantees, in a way, a holistic and in-depth understanding of the phenomenon in question. We carried out a triangulation process by using multiple sources to obtain information from the case study. A total of 2 categories of analysis emerged: based on the proposed research goals; based on the theoretical framework, particularly, on the approach to Education for Sustainable Development proposed by UNESCO [17] in the context of the global south [18] for the eradication of a serious existing environmental problem in Ghana derived from the lack of plastic waste management [4], as well as the educational use of this approach as a germ of social and ecological transformation $[19,20]$; and based on data classification and processing: (a) awareness of plastic and its properties and (b) use of plastic for the production of teaching and learning materials.

Both the methodological design and the data collection followed the ethical guidelines of qualitative research. First, the informed consent of the management and educational community of the public school "Wulugu Project" was obtained for the planning, development, and evaluation of the educational project, the research based on the results of this project, and the recording of videos and photographs. Further, efforts were made to preserve the confidentiality of the informants, guaranteeing their anonymity/identity. Likewise, the research findings are intended for academic dissemination and the aim was to improve awareness of plastic waste among students. In this research, an ethical commitment has been made to contribute to the formation of a critical global citizenship for Sustainable Development in Ghana through processes that deconstruct global oppressive, hegemonic, and post-colonialist structures. 


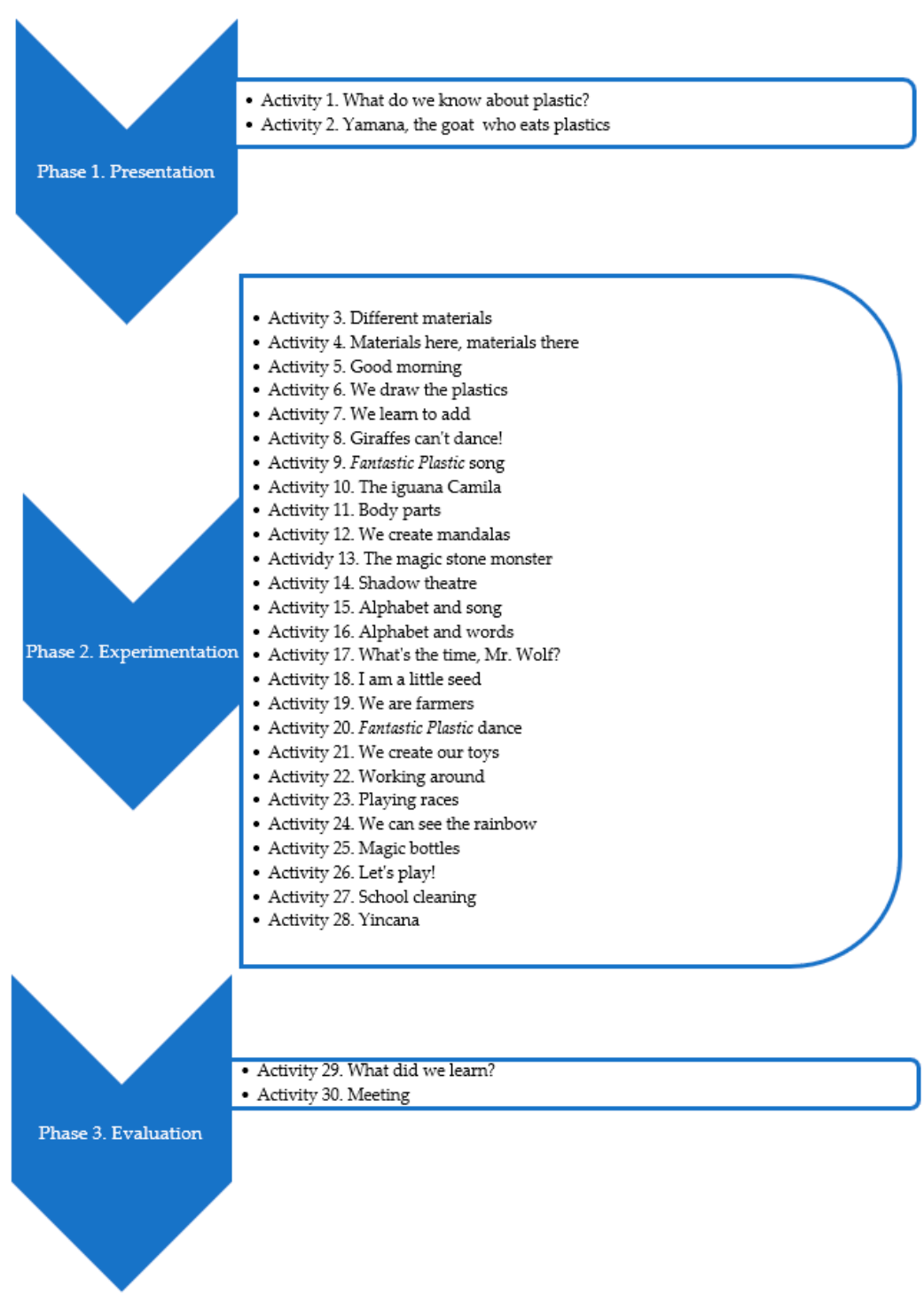

Figure 2. Phases, sessions, and activities of the educational project.

The research arose from a project aimed at raising awareness among schoolchildren about the use of plastics and their impact on the environment. This project was designed in the context of educational cooperation promoted by the University of Valladolid (Spain), through the NGDO ADEPU, with two local partners: the "Wulugu Project" public school and the Ghanaian Glory Land Foundation (these organisations are mentioned in the acknowledgements section). We have maintained this horizontal relationship uninterruptedly for a decade, which has allowed for an exchange of experiences and educational and methodological knowledge between Spanish students and Ghanaian teachers. This continuity and the good practice that is unaccustomed in relations between the North and the Global South have resulted in a reciprocal relationship that is deeply enriching and full of respect and affection on both sides. Recently, the European Union has approved the award of the Erasmus K107 Project for teaching and research collaboration, including funding for reciprocal mobility, between the University of Valladolid and the University of Ghana, which will allow for the creation of new systematic scientific and teaching projects between these institutions. In this research, we are committed to contributing to the creation of a critical global citizenship through processes that deconstruct oppressive, hegemonic, and post-colonialist globality. In carrying out the design and implementation of the educational intervention, we collaborated with and were supervised by native teachers from the 
"Wulugu Project" public school who, despite declining the invitation to collaborate in the research and writing of the paper, form the backbone of this article.

\section{Results and Discussion}

\subsection{Raising Awareness of Plastic and its Properties}

To know more about the students' previous knowledge about plastic, early in the project we implemented the activity "What do we know about plastic?" complemented by a KWL thinking routine. It became clear that the children's knowledge was mostly concerned with the daily use of plastics: "it helps us for eating". They stated that it was used as a material for food transportation and packaging [21]. "It makes pii water", they said, as the only access to safe water is in $500 \mathrm{~mL}$ plastic bags that they know as "pii water". This link between plastic and food helps children see only the impact of the former on the latter and the improvement of their daily lives, as well as a possible source of income for the family, but not its negative impact on the environment. One of the students stated that clothes were made of plastic, and they also did not understand that the same object could be made of different materials. All this showed that the students did not have a basic knowledge of plastic and did not differentiate it from other materials. Given this fact, the first stage of the educational project involved experimentation with plastic to understand the properties of this material so they could identify it and understand how it differs from other materials. This subject would be worked on transversally throughout the project. Through the initial activities, the children had the opportunity to observe, manipulate, and analyse the texture and smell of plastic and thus, verify how it differs from paper, fabric, wood, or metal. They did so using everyday objects, such as their notebooks, typical Ghanaian clothes, twigs from the trees in the courtyard, and metal spoons, and then classified and distinguished them from the plastics, thus identifying their use in their closest environment.

This morning I continued with the plastics project. (...) After the Literacy assembly, in which I usually work on the alphabet, colours, parts of the body and animals, I wanted to introduce new content: materials. I think that it is fundamental that the students understand the importance of plastics and the effects they have on the environment, that they identify what plastic is, what types of plastics there are, and how to differentiate them from other materials. With this objective in mind, I began with an introduction to the taxonomy of other materials: wood, glass, stone, rubber, plastic, metal and paper. To teach them this, I showed them different elements of their environment and culture so that the students could make a better association. The result was very good, they showed great interest in the activity and especially in experimenting with the materials.

-Excerpt from the teacher's journal.

As examples, the teacher brought into the classroom a wooden spoon, a metal spoon, and a plastic spoon to show that the same object can be made of different materials (see Figure 3). Likewise, in Activities 3 and 4, the students were put in a circle and had to guess what object was inside an opaque bag that the teacher taught with the song "Materials here, materials there, materials everywhere". Through their sense of touch, the students had to discover what the material was. With this, they learned not only the name of the objects but also some features of the different types of everyday objects presented (spoon, pencil, scissors, eraser, notebook, and so on). 


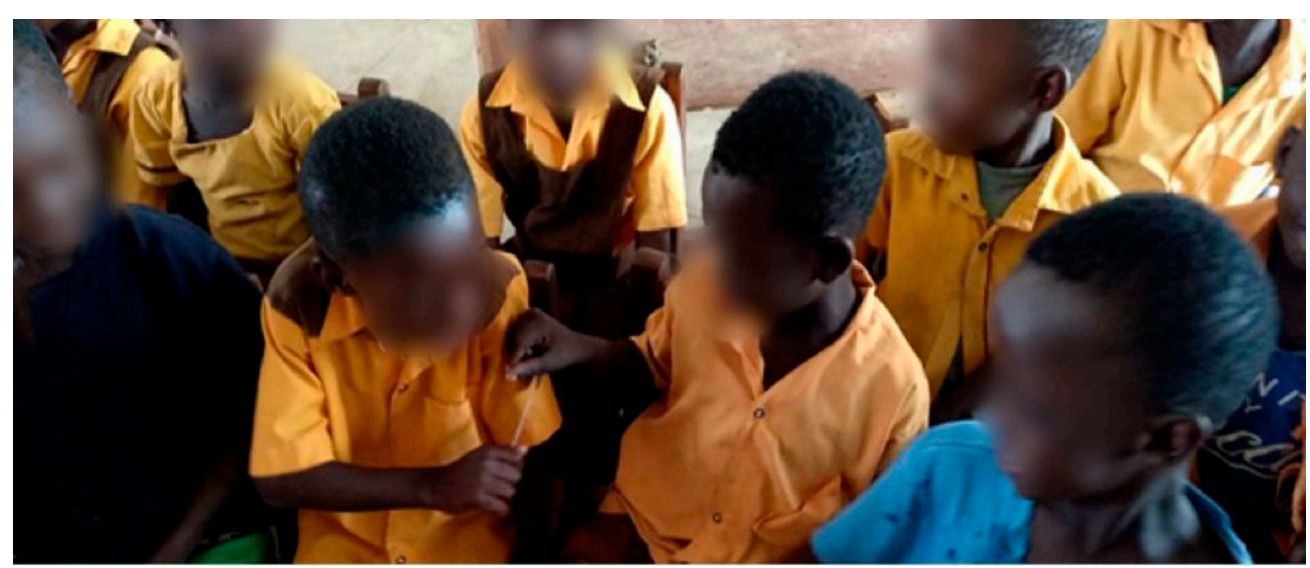

Figure 3. Still image from video recording of Activity 3: Different materials.

In a country whose rivers and seas are littered with plastic waste, only one child pointed out that plastic was not good for the environment, while the rest of their classmates saw it as a facilitator of their lives, not reflecting on its harmful effects on Ghana's flora and fauna. Even though the Ghanaian curriculum includes the subject of environmental studies [22], it seems that the contents on the environmental consequences of plastic consumption had not been internalized. Figure 4 shows the sea of plastic that covers the surroundings of the Larabanga school.

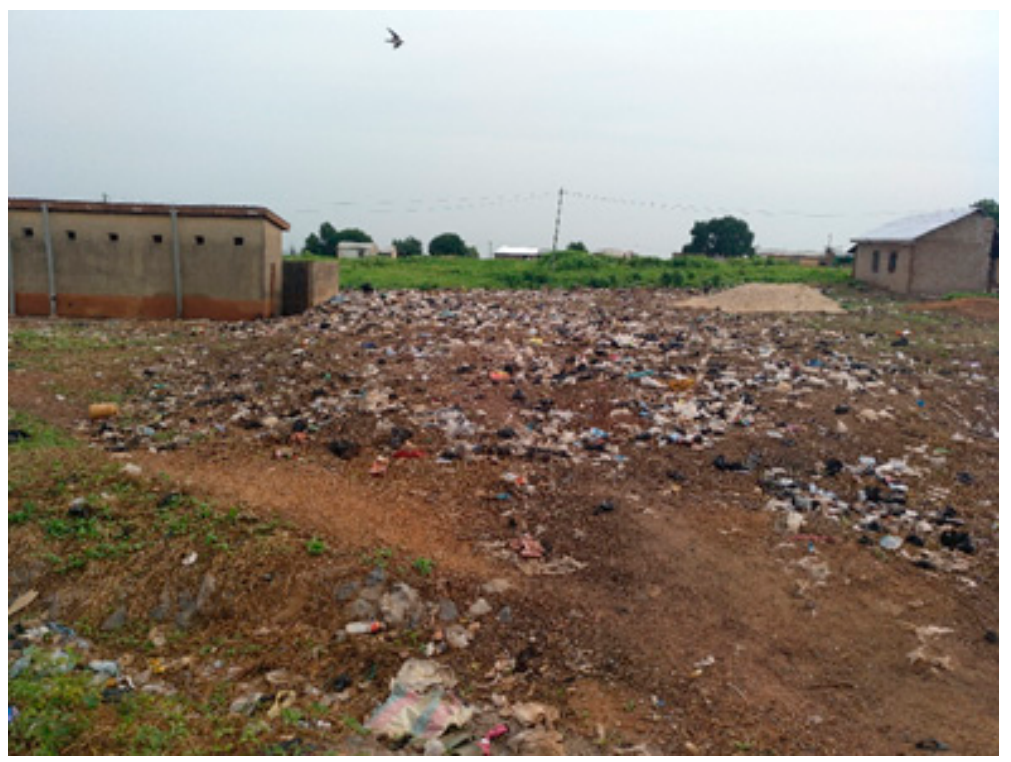

Figure 4. Photograph of the context surrounding the school in Larabanga (Ghana).

Globally, and especially in Ghana, plastics cover all sorts of environments, from freshwater to seawater [23], from urban areas to remote areas [24], and from the beach to deep-sea sediments [25]. In Ghana's waste dumps, the proportion of plastics is much higher than that of other materials [26]. The usual landscape is one of land and rivers littered with plastic, which is not readily biodegradable and takes anywhere from 2.5 to 5000 years to decompose [27]. It causes the clogging of drainage systems and massive flooding across the country [28], in addition to the pollution it generates and its consequent danger to people's health and the ecological integrity of the environment.

In a widespread practice in Ghana, children participate from an early age in the hoarding of plastic waste and its subsequent burning as a common disposal procedure, as shown in Figure 5. This practice results in the release of toxic heavy metals and greenhouse gases, such as dioxins and furans [27]. It also contributes to the deterioration of the 
environment, global warming, and the acceleration of the climate crisis that is affecting our planet [29]. This proves that government policy efforts to address plastic pollution are insufficient and immediate action is required to regulate and restrict the unnecessary use of plastic and promote its reuse instead.

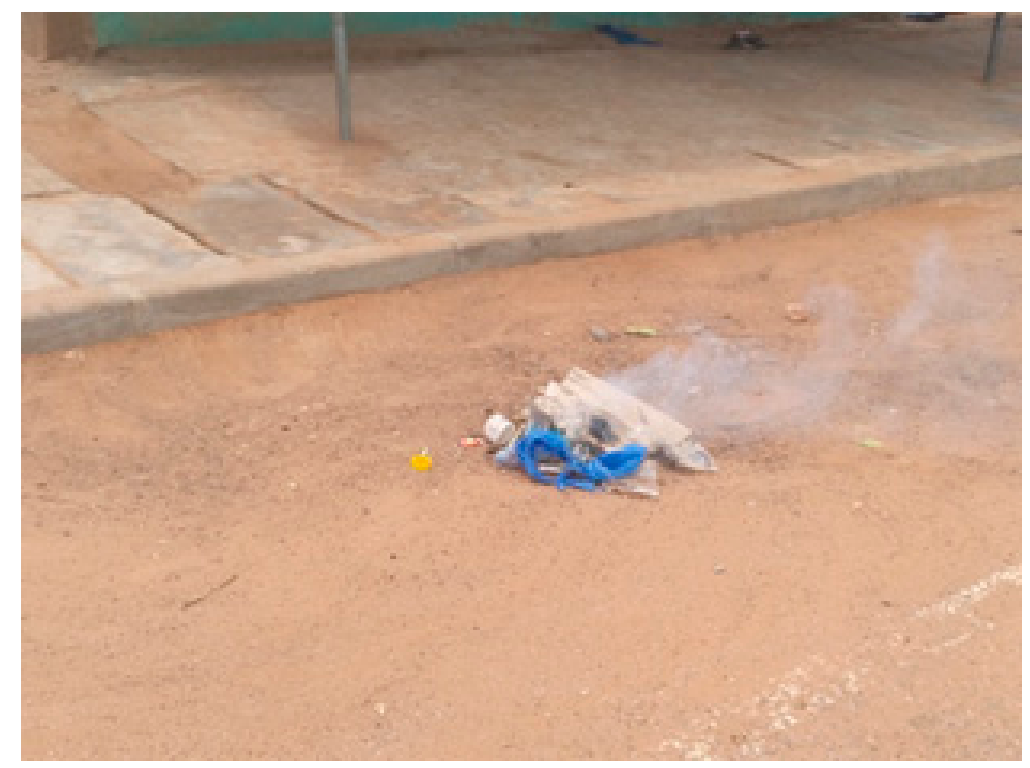

Figure 5. Burning of plastic waste.

The main activity in this first category was "Yamana, The Goat Who Eats Plastics". This was the guiding story of the entire educational project. We took advantage of the abundance of goats in the village to create a character that would surprise and guide the students to learn about the harmful effects of plastic and its impact on the sustainability of the environment. The storytelling made the children empathise with Yamana, the plasticeating goat (Figure 6). They became aware of the damage that plastics caused to Yamana's health, such as the obstruction of its digestive tract or internal injuries that reduced its nutrition, which could lead to its death [30]. The effects of plastics are particularly harmful to marine wildlife $[31,32]$.

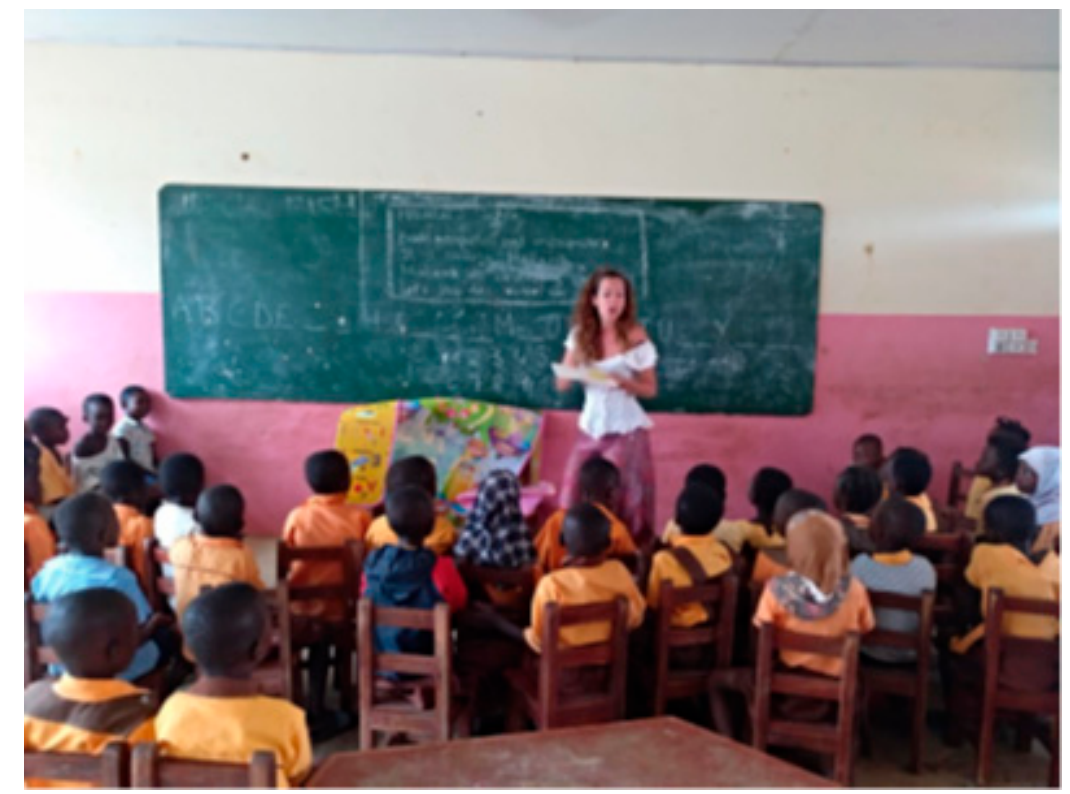

Figure 6. Narration of the story "Yamana: The Goat Who Eats Plastics". 
And suddenly, Yamana started to throw up because of all the plastics she had eaten.

- Yamana: I feel really sick! Please mom, dad, I need some medicine.

- Mom: Yamana, what did you eat this morning? I don't understand why you feel sick.

- Yamana: Sorry mom, I ate some plastics.

- Mom: I can't believe it! I've told you a thousand times how bad plastic is.

- Yamana: I know, mom. But all the children throw plastic on the ground.\}

-Fragment of the story "Yamana, The Goat Who Eats Plastics".

After the story had been told, the children collected different materials from the playground and placed them in the centre of the classroom (Figure 7). Almost all of them were plastic residues. They were then asked whether plastic was good for the environment. Their arguments were quite different from those expressed at the beginning of the project. Some remarks were "It is really bad for the animals" and "It destroys nature". In fact, the story helped them become aware of how harmful plastics can be in their lives and the importance of reducing this type of material in their immediate natural environment.

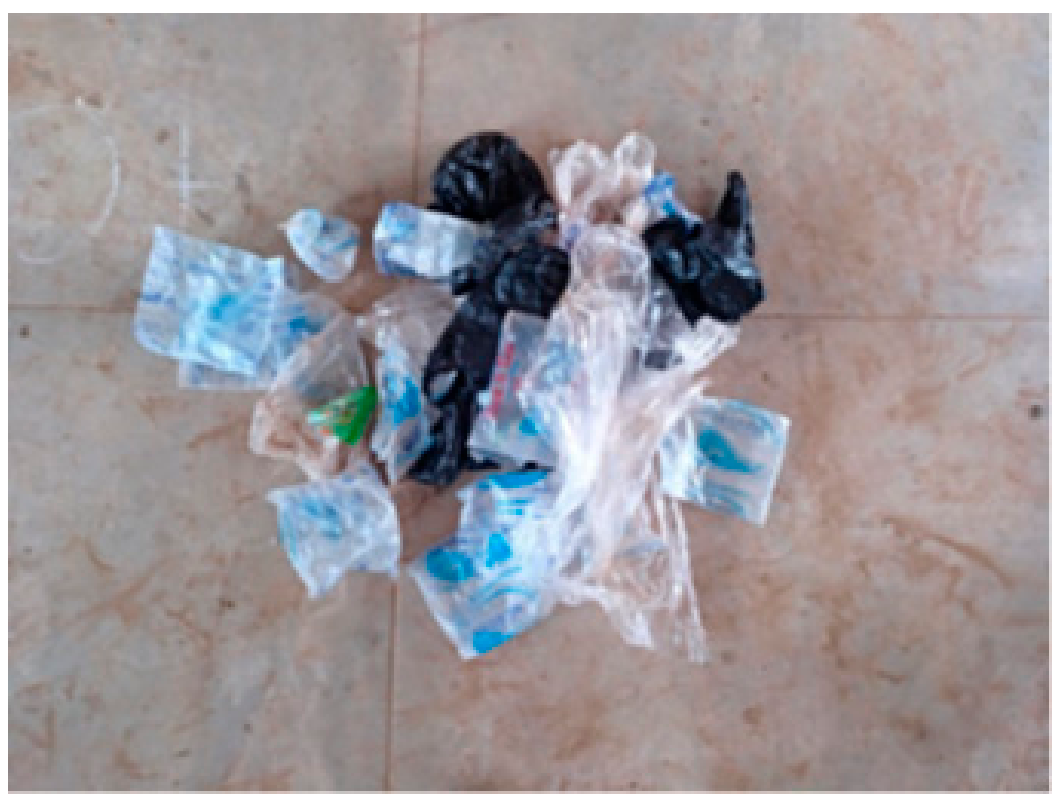

Figure 7. Collection of plastic waste from the school yard.

Throughout the project, awareness and involvement in the issue of plastics was increasing as the school was to commit to the task of educating for sustainable development in the face of climate change [33]:

I have been able to appreciate the great progress made in raising student awareness from 0 to 100. The students have gone from knowing nothing about the harmful effects of plastic on the environment to not only assimilating it but also transferring it to their daily lives. This denotes not only great learning but also real awareness of the subject.

-Interview with observer teacher, p.124.

Awareness of the consequences of plastic in the context closest to children was fostered by play and musical expression. The teacher, with the help of the children, composed a song for the "Fantastic Plastic" project. Recent research indicates that simply increasing knowledge about environmental problems does not correlate with increased pro-environmental behaviour [34,35].

Hey teacher! Hey children!

I am a little piece of an amazing world 
Reusing plastic

It is fantastic

You can use it for whatever you want

Use your imagination for your next creation

Come on children take the bottle

(repeat)

I am saving the world

now nature is clean

I can do with this plastic

whatever you think

I can learn in school

all the subjects, it is great

Gonja here, English there

and mathematics

You can learn,

you can play

If you say I'll change the world

(chorus)

Come on children, take the bottle

$a, a, a$, oh....yeah

Come on children, take the bottle

whoa, whoa,...

(repeat)

Motivating students to engage in such behaviour requires a combination of pedagogical approaches that includes affective/emotional components, such as learning through the arts [36,37]. In this sense, a greater role for the arts in environmental education is of interest because it generates positive and negative emotions and feelings $[38,39]$. The integration of music into environmental education can help to elicit pro-environmental thoughts and actions as a result of a combination of social, psychological, and physical factors [40].

Choreography associated with the project song was also created (see Figure 8). The play moments in the breaks were made dynamic for all the students with this musical creation, as a sign of the link between art and soundscapes in environmental education [41-43].

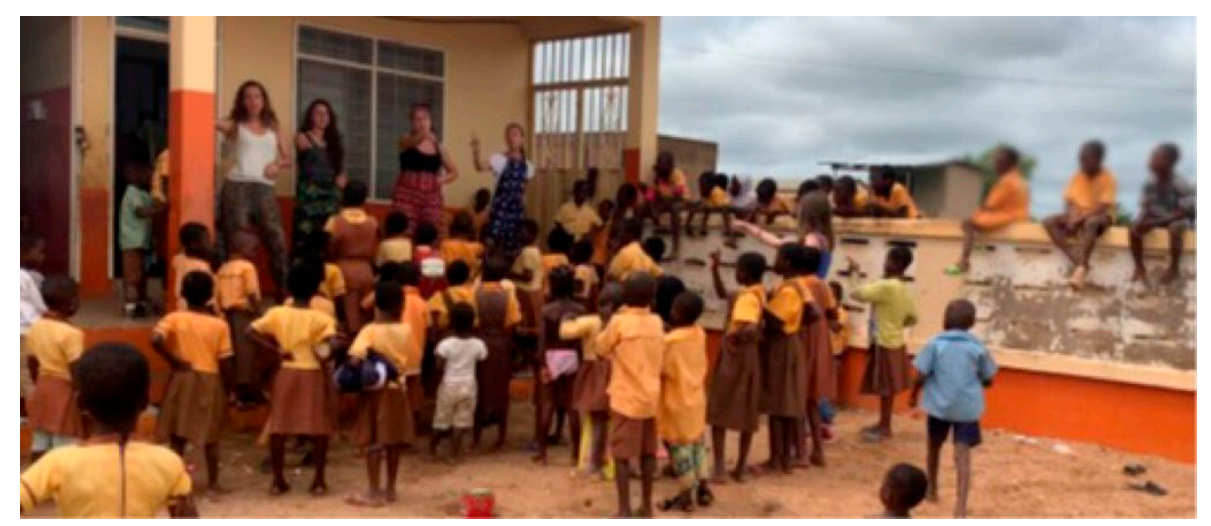

Figure 8. Choreography of the song from the "Fantastic Plastic" project.

Finally, we would like to highlight an activity proposed by a student, as a sign of the degree of interest and awareness generated by this project. The student suggested 
gathering to pick up plastic waste in the schoolyard, so that everyone, children and teachers alike, would participate in the collection of plastic waste, as can be seen in Figure 9.

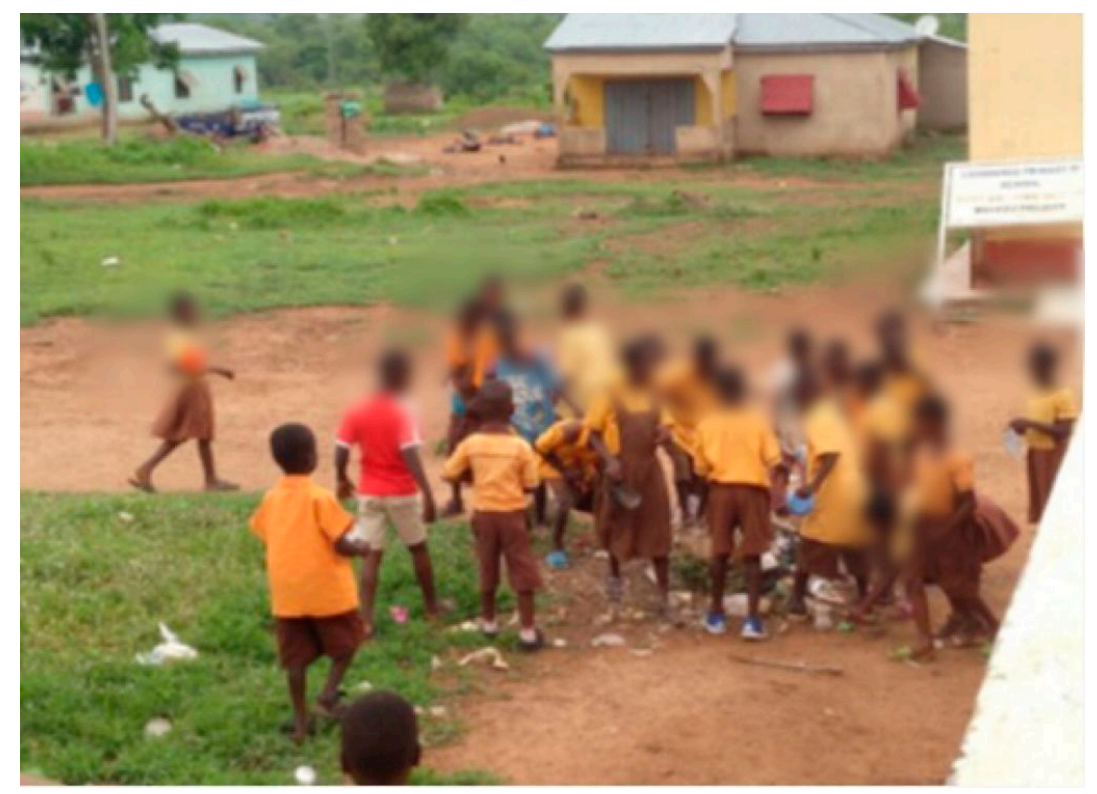

Figure 9. Schoolyard plastic waste clean-up squad.

I thought it was an excellent idea for us to do this work together, since their interest and awareness was such that they did not want to see their common spaces so dirty and full of plastic. Further, the idea came from them. That denotes real learning, from emotions and the heart.

-Teacher's class journal, p. 15.

Despite having promoted greater awareness of plastic waste, adequate management of plastic waste is still far from being achieved. Climate policies must be put in place at the national level in Ghana for the collection and proper treatment of plastic as an alternative to burning or dumping it out in the sea. In addition, a transition to a lower-carbon economy should be properly funded [44]. In the current context of climate change, these facts show the need to develop new attitudes and new forms of production and consumption in this African country that will contribute to more ecologically sustainable socio-economic development [12,45].

\subsection{Using Plastic for the Production of Teaching and Learning Materials}

Throughout the project, awareness on the issues surrounding plastic increased, while the children learned how to reduce and reuse it in the face of a climate emergency in a country where the annual waste recycling rate is only $2 \%$ [46]. Environmental education is necessary for it to be possible in the future not only to solve these problems but to stop generating them altogether [11]. The indiscriminate use of plastic and its negative impact on the environment for generations requires adequate plastic waste management [47]. In our project, the reuse of plastic emerged as an ideal and useful proposal for the creation of educational and recreational materials in Ghana, a country that urgently requires environmental education on plastic disposal [48].

The prevailing methodology in the Ghanaian school system is based on the colonial system imposed by the British Empire [49]. It is fundamentally centred on discipline and authoritarian control of the classroom. Literacy and calculation are learned by rote, through repetition [50]. Nevertheless, Ghanaian education enjoys high social recognition as a tool for community development and social and labour insertion [51-53]. Plastic and its reuse became the base for learning other curricular content [54]. For example, in the activities "Numeracy" and "We learn to add" (see Figure 10), bottle caps were used for counting and 
learning addition, turning plastics into teaching material. The association of a number with the quantity of caps, and the possibility of counting and adding them in a manipulative way, helped the students learn to add up to ten in a simple, fast, playful way. Working in the classroom with waste materials, such as plastic caps, generated active learning where the children "learned by doing" and "experimenting" [55,56]. They also developed scientific and reflective attitudes about the reuse of this material $[48,55,57]$. The experience helped create experiential learning [58], far from the traditional Ghanaian mathematics learning experience, which is not very meaningful or comprehensive, but rather mechanical and repetitive.

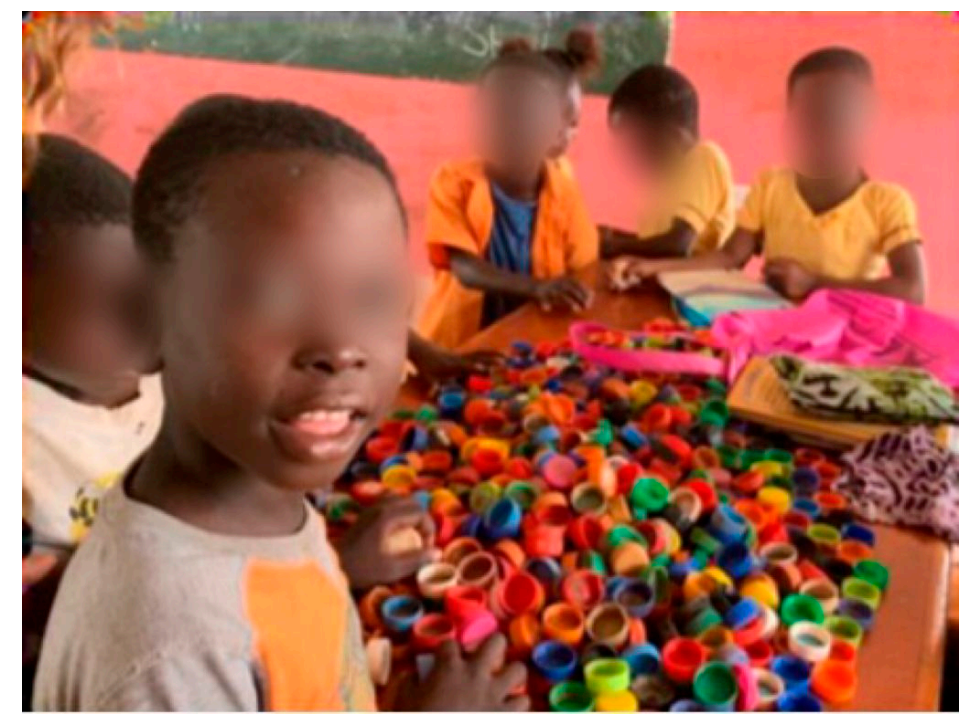

Figure 10. Activity with bottle caps, "We learn to add".

After learning to count and add, new activities were developed that allowed these learnings to be consolidated. Figure 11 shows a student associating a number with a quantity using plastic bottles and sticks from the surrounding area. The project really helped the children autonomously and responsibly become the agents of their own learning. It was a learning process that enabled the creation of new mental structures, following a constructivist approach to knowledge [59], seeking an education for the climate crisis from actual practice and from the students' previous experiences [10].

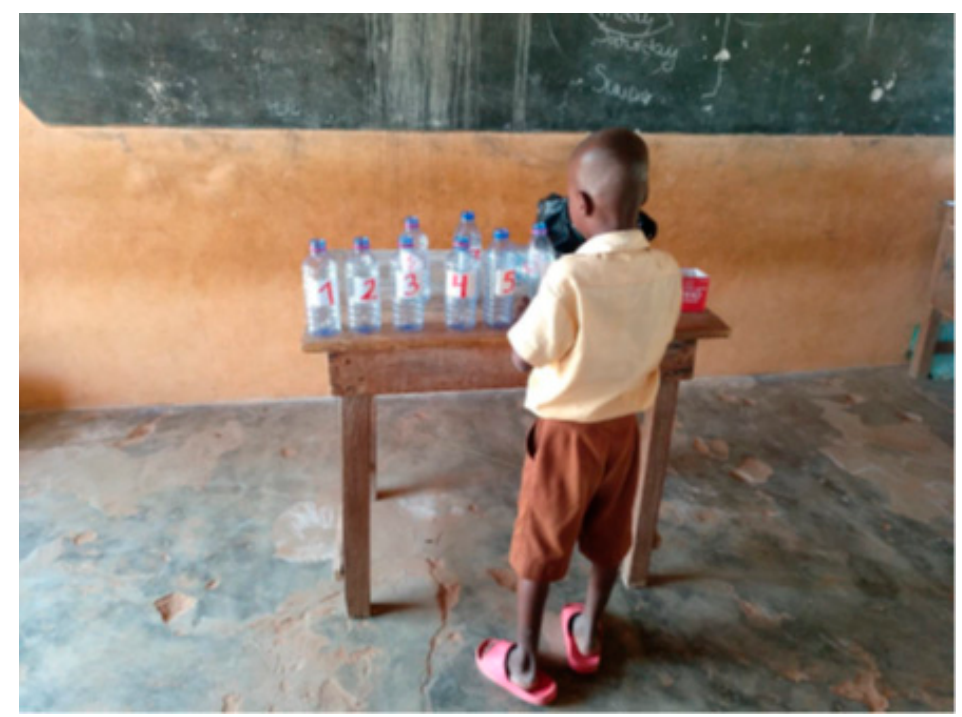

Figure 11. Associating a number with a quantity. 
In Figure 12, we can see the use of two plastic bottles for the creation of "The magic stone monster", a stone-swallowing machine that helped the students do sums by introducing stones into each of the bottles. At the end of the operation, the total could be counted on the plastic machine itself. On the third day, one of the students stated that thanks to the monster he had learned to add easily; "Adding with the monster is really fun, it helped me!" (teacher's journal, p. 65). The interaction with the waste material activated the scientific process and provided a real experience to think about and question how to perform a specific task and why [60].

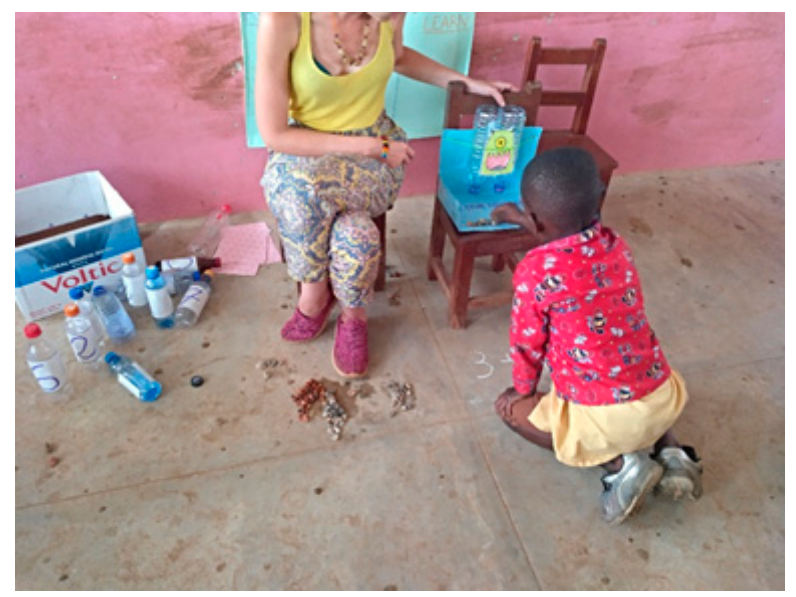

Figure 12. "The magic stone monster".

As stated above, in Ghana, the learning of mathematics prioritizes mechanization and rote learning. Working with recyclable materials makes it possible to rethink how to work with mathematical content using familiar objects, ubiquitous in the students' daily lives. In this way, the use of recyclable materials in mathematical games brings the students closer to meaningful learning, since it favours reflection and analysis of specific situations related to the real world, providing context and motivation for learning [61]. Figure 13 shows the material used for one of the literacy activities. The alphabet was constructed using 26 bottle caps in different colours. The aim of this activity was to identify the letters, to associate the sound of the different letters with their graphic representation, to sing songs, and so on. Once this content was consolidated, the students were guided in the construction of new words (see Figure 14). In this way, they learned to write their name, the days of the week, the names of their parents, or the town in which they lived.

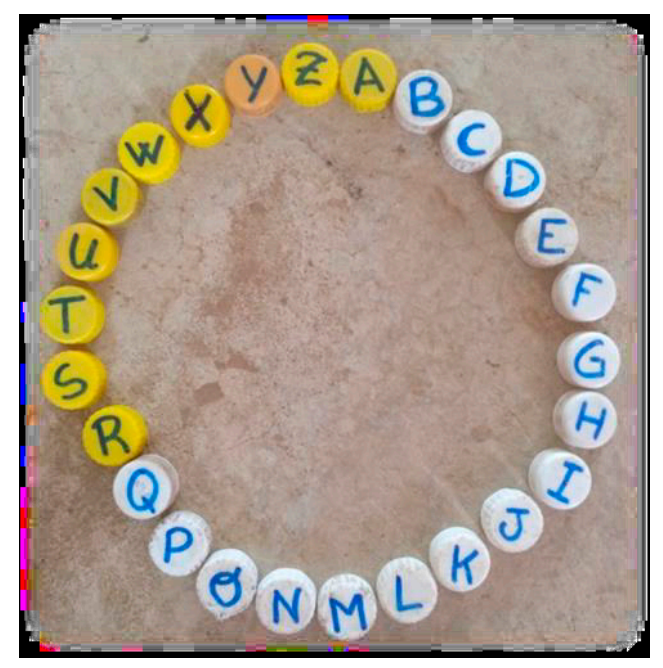

Figure 13. "Alphabet and song" (I). 


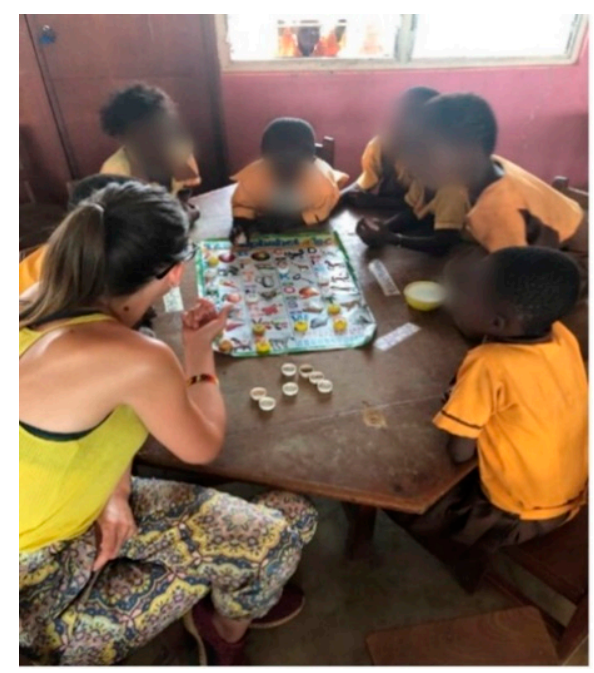

Figure 14. "Alphabet and song" (II).

Plastic waste was reused to develop dynamic activities to consolidate learning contents. These activities were really successful, mainly due to the fact that the approaches used were new and adapted to the children's learning rhythm. The children created puppets with the plastic waste that they brought to class, as can be seen in Figures 15 and 16. The puppets were used to tell stories that were contextualised in Larabanga. They used animals typical of the region and places that were familiar to them.

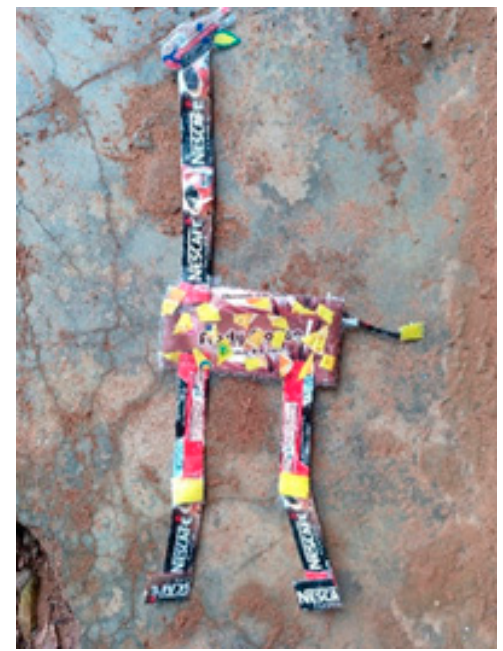

Figure 15. Puppet created for the story "Giraffes can't dance".

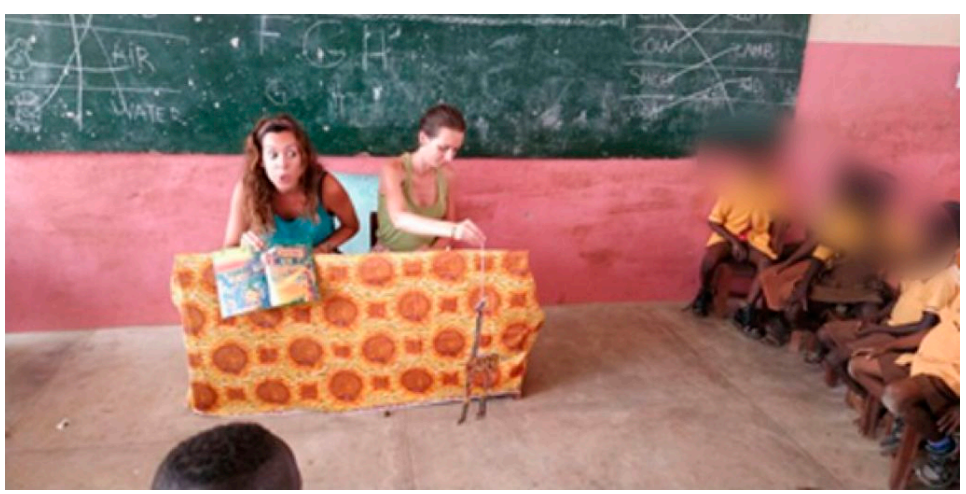

Figure 16. Performance of the story "Giraffes can't dance". 
During the project, the children also worked on their art skills. They were asked to use plastic to make works where they could express their creativity and imagination. Artists and academics such as Lin Evola-Smidt, Michelle Reader, Ptolomeo Elrington, and El Anatsui, to mention a few, have used rubbish or waste materials to make works of art [48]. Many studies show that the creation of original and purposeful artworks from waste materials provides students with unique opportunities for the development of a rich and motivating learning environment, as well as critical and creative thinking [62] in creative and expressive visual arts experiences [63]. Likewise, the transformation of waste into appropriate learning materials for teaching art is considered a valuable contribution to an artistic reflection of people's beauty and sensitivity [48]. Aesthetically, when working with material waste, the notion of waste is abandoned, and a new point of view and appreciation of waste materials emerges. When waste is transformed into something extraordinary, it remains within the aesthetic realm of producing teaching materials [64]. Furthermore, in this project, the waste materials were culturally appropriate to the students, given that they could easily relate to these materials because of their ubiquity in their immediate environment [65]. Thus, we developed the activity "We create mandalas". In this activity, the children combined elements from nature with plastic waste to create artworks. As can be seen in Figure 17, one of the children represented his home using CDs and pii water bags. Another student preferred to use only natural elements because she no longer liked plastic, as can be seen in Figure 18. Waste paper, plastic, and cloth can be safely reused to create very useful and appropriate teaching materials that can serve as resources for art education [53]. As can be seen in the works of Ghanaian artist Serge Attukwei Clottey, real wonders can be achieved using plastic [66]. Improved manipulation skills, fine motor skills, and visual/spatial thinking skills have been shown to be predictive of success in scientific subjects [67].

As can be seen In Figure 19, the children also worked manipulatively with other environmental materials such as clay and, in addition, they learned Ghanaian curriculum content, such as body parts and clothing, contained in Section A, Building a Healthy Individual [22].

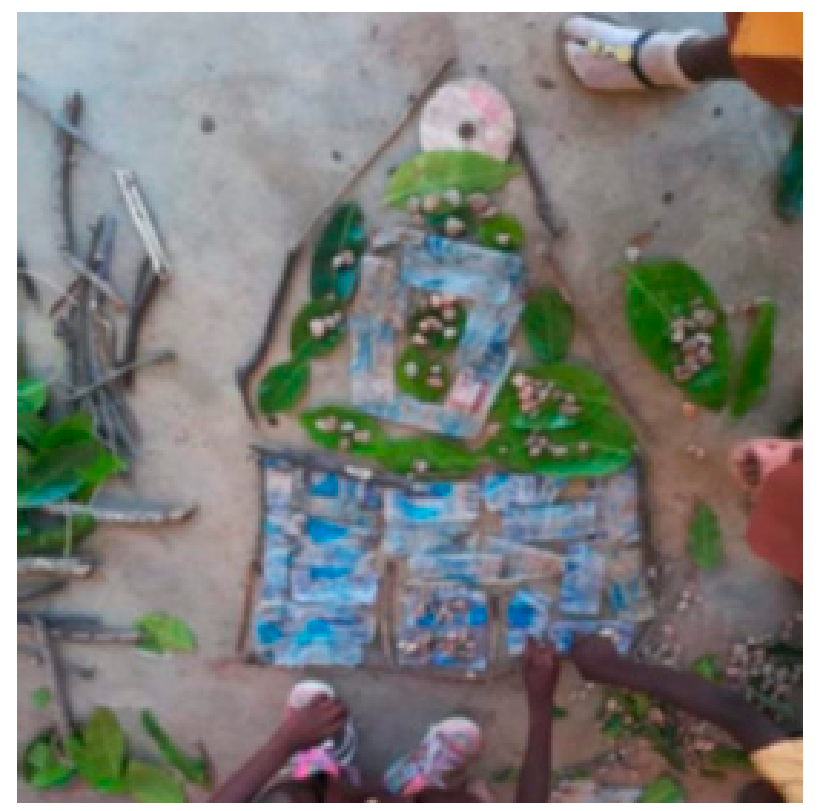

Figure 17. Artistic creation with plastic waste. 


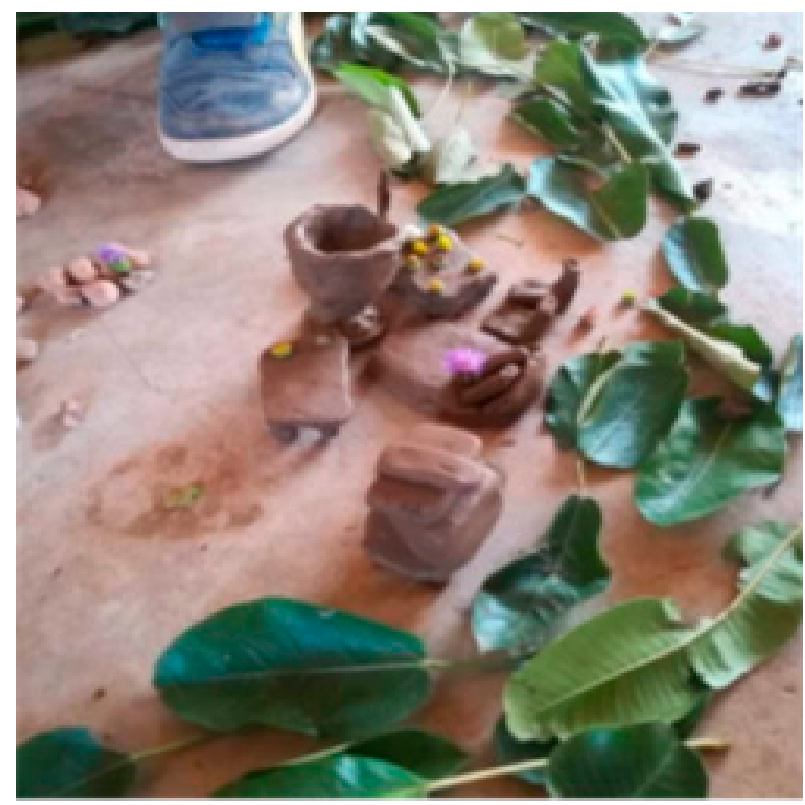

Figure 18. Artistic creation with natural elements.

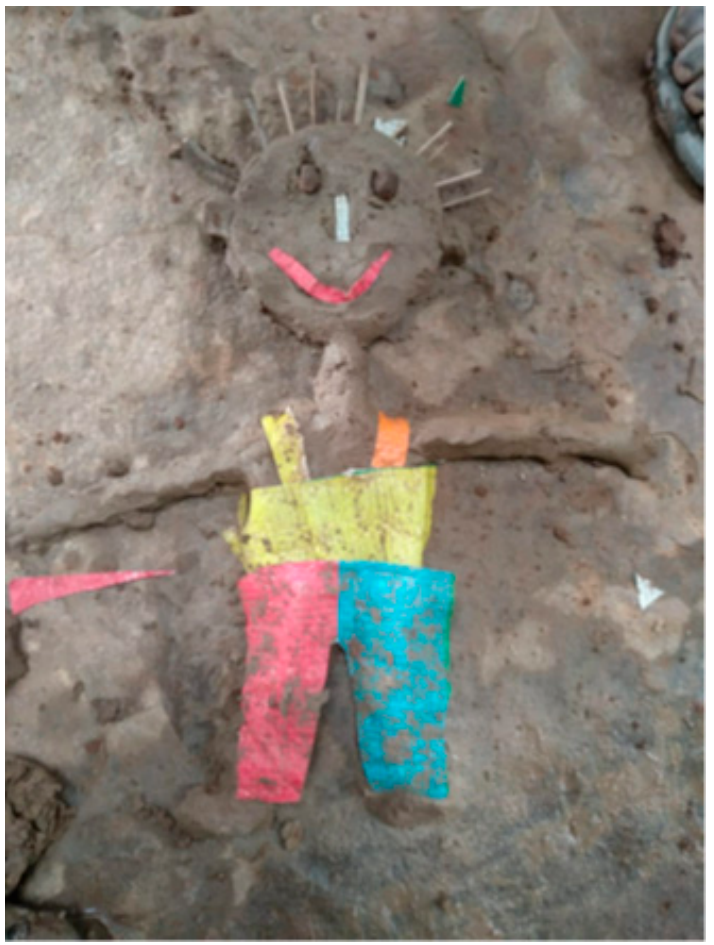

Figure 19. Doll made of mud and plastic.

In Larabanga, most of the population is involved in agriculture and trade. Therefore, it was important for the children to learn how plants grow, as well as how to care for them. Figure 20 shows the result of the activity "We are farmers". Each of the students brought a bag of pii water to class, cut it at the top, filled it with soil from the area and sowed a sesame seed in it. 


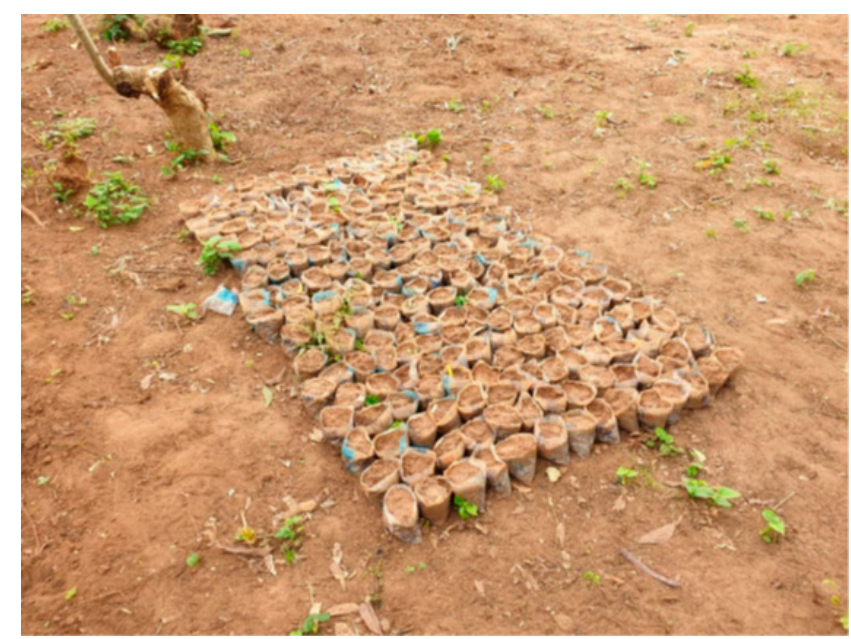

Figure 20. Sesame plantation with reused pii water bags.

From the beginning, the students became involved in the project, bringing materials, collaborating in the activities and showing the community what they have learned about plastic. On several occasions, we were able to see children and adults from the village carrying out the same activities that we had done in class. Not just the children, but many adults also started reusing plastic waste that would have otherwise been discarded.

-Teacher's journal, p. 70.

In a country where agriculture is the primary source of livelihood of most people, practical environmental projects are essential because the more knowledge children have about plants, the more they will appreciate and protect them in the future [68].

Given the improvement in motor skills shown by the children, this potential was used to encourage them to create toys by reusing plastic waste. In this regard, the pupils continued to develop their imagination and creativity with a playful purpose, and it was the teachers themselves who learned from them how to make balls, jump ropes, cars, and dolls from plastic waste. Many children claimed to use plastic almost daily to build their own toys. For example, they made footballs using pii water bags, and they used plastic bottle caps and soda cans to make cars like the one in Figure 21.

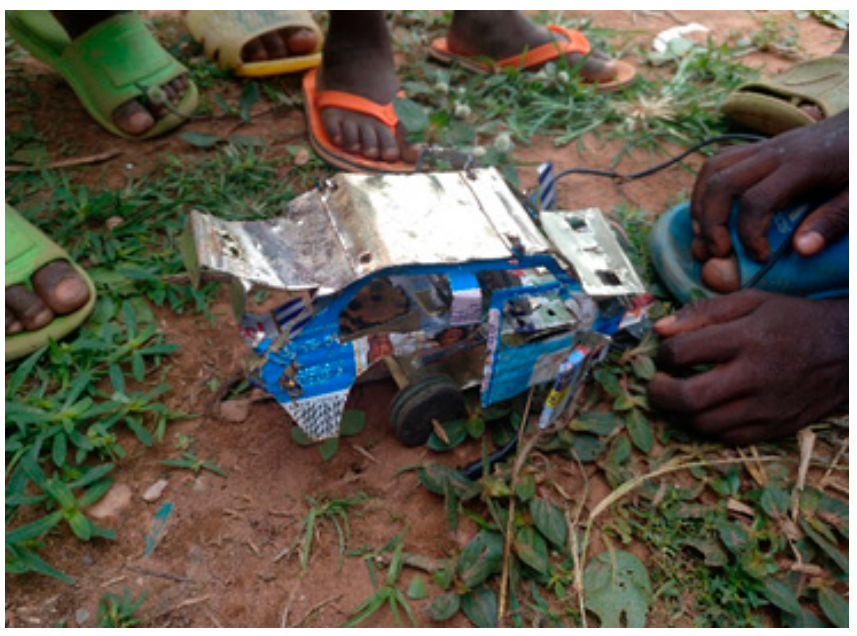

Figure 21. Making a car with plastic waste.

The children also used pii water bags to make jump ropes for the playground. To do so, they cut the sides out and tied them together, as can be seen in Figure 22. 


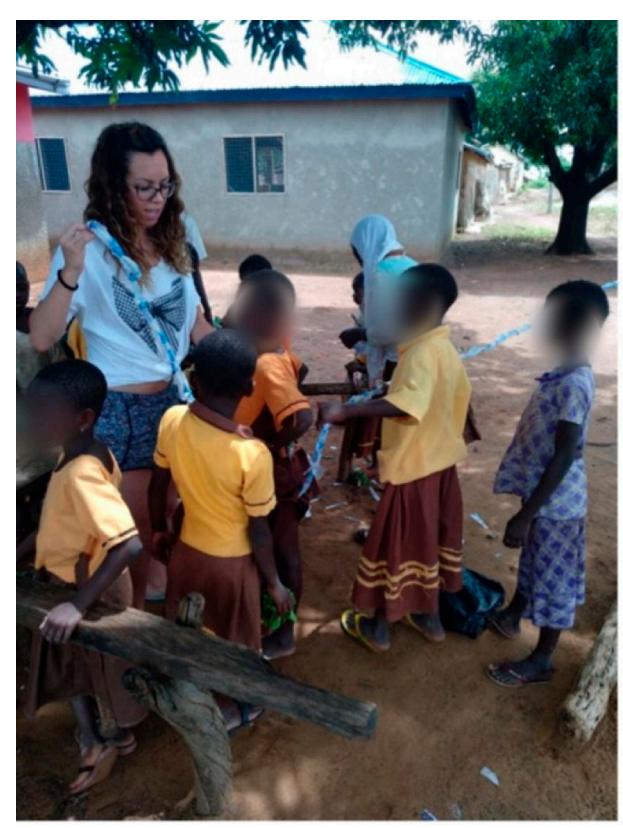

Figure 22. Making a jump rope with pii water bags.

\section{Conclusions}

The environmental situation in Ghana in recent years is alarming, and it is already having serious consequences, especially regarding the increase in plastic production and consumption [69]. Although some measures have been taken, we cannot ignore the problems arising from this situation in many areas. In this article, we have presented and discussed the results of the "Fantastic Plastic" project, which intended to improve sustainability by understanding how much time we have left to increase our quality of life. This project is in line with the UN's 2030 Agenda, whose strategic objectives include the drastic reduction of plastic production and consumption as well as education to foster this reduction. In this regard, we have considered it appropriate to introduce plastic as a learning content and educational resource [54].

In any learning process, when following the steps of the scientific method, a requirement prior to knowledge is observation. This is what the first category of results, as seen in Section 3.1: Raising Awareness of Plastic and its Properties, was about. It gathered the results about the degree of awareness of the students about the polluted environment of Larabanga, exposing the social responsibility of the school as an agent of change and social and democratic development. Through activities in this category, developed through a communicative and participative methodology, an important change in perception took place in the participating students, from a practically complete lack of knowledge to a critical understanding of the magnitude of the problem. Moreover, the project acquired a systemic scope so that the children and the entire educational community assumed a commitment that elevated the idea of the project to a higher concept, a new reason to fight for a more habitable and sustainable world.

In the second category, as seen in Section 3.2: Using Plastic for the Production of Teaching and Learning Materials, the drive for learning connected to reality became apparent-learning based on the students' experimentation with the material and interaction with other students. This has allowed for the solidification of a class group motivated by knowledge and overflowing with ideas and imagination. As shown in the design and implementation of the project's activities, we need to understand learning as an innovative and creative process. There are many ways to deliver knowledge, one of which is by providing learning experiences. The results of the project show that the learning acquired soon became part of the students' daily lives, and later spread to the lives of their teachers and promoters. After all, this is how we work for global citizenship-driven by reflection 
and action. Quality education is both a goal in itself and a means to achieve all the other SDGs; it is an integral part and a key facilitator of sustainable development [70].

The exponential growth of plastic production places the countries of the global south at particular risk. These countries accumulate tonnes of waste from other countries as well as their own. Furthermore, they often conceive of plastics as a prosperous material that is beneficial for the food industry, construction, and transportation, regardless of how this flood of plastics can increase their vulnerability [71]. Plastics also affect people in many other ways beyond pollution. This is why we believe that proposals such as the one presented in this article are so important. In reality, it is a matter of education for the global citizens who are aware of the need to create a sustainable world with a view to the problems that affect and determine its future [72]. However, education for the climate crisis does not produce results if it is only theoretical [10]. Therefore, it is necessary to promote an educational commitment to environmental sustainability through active, cooperative, analytical, and critical learning, implementing proposals for action that call upon students to put their knowledge and reflection into practice. This environmental education, promoted by schools through citizen participation, will enable the design of an alternative for the future aimed not only at solving the problem but at preventing it altogether [11]. This is a decisive step that we have been able to observe in the students who were the subjects of this study. The first challenge, then, lies in making the children feel part of a possible solution to climate change, in making them feel that they are part of the problem as well, and in encouraging them to acquire a personal commitment based on a deep understanding of the context and of the value of the contributions that they, their peers, and other local actors can generate together. We must be confident that there are already new generations around the world exercising engaged critical citizenship. Their professions, actions, and decisions will, in due course, impact social reality. In the meantime, the growing effort to provide sustainable, equitable quality education must continue.

The project described in this paper had a tangible impact during the period in which it was implemented. As mentioned above, this impact was felt in the school environment, but it also carried over into the students' daily lives. It was not uncommon to see students around the school, after school hours, collecting plastics to bring to class or with which to make toys. In one instance, as seen in Figure 23, we found an adult from the village making dolls out of pii water bags, as the children had done a few hours earlier at school.

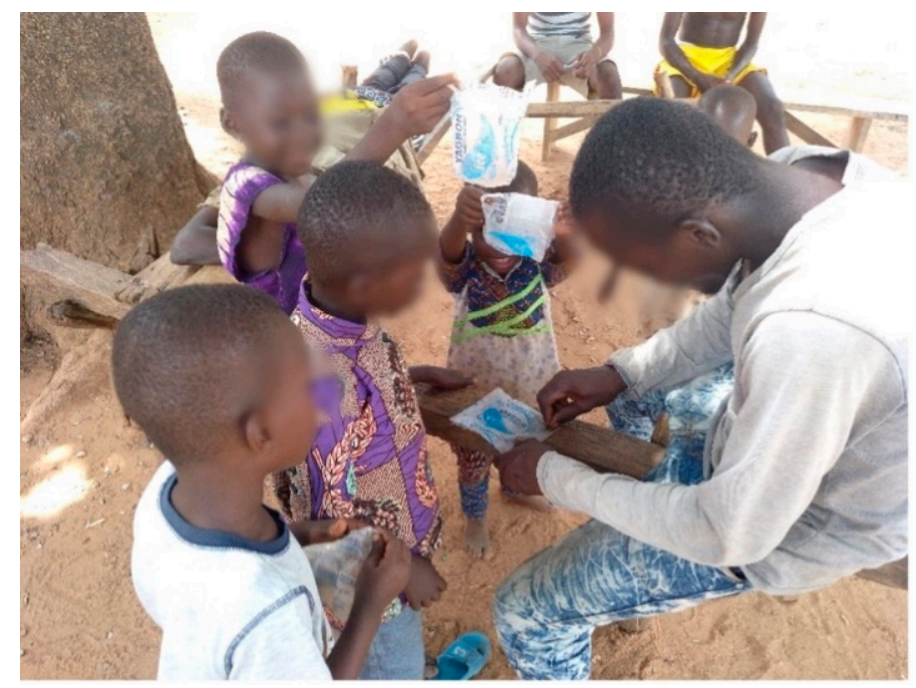

Figure 23. An adult making dolls with pii water bags.

The students and the teacher became so involved in the project that they made it their own. Soon they were much more interested in the environment, discussing the effects of climate change and pollution in depth. Teachers from other educational stages became interested in the project and decided to take an active part in it. All the materials 
created for the project were kept at school for later use. Moreover, the researchers, through the University of Valladolid and the NGDO ADEPU, maintain regular contact with the headmaster and the schoolteachers, who, before the pandemic and the closure of the schools, proudly told us that they were still implementing some ideas of the project at school. It is true that this was an ad-hoc, small-scale project and, although it included training and feedback to the teaching staff, it is still but a drop in the ocean.

As we have noted in the theoretical framework, these experiences must be accompanied by effective policy-making, because, although it is important to foster a critical conscience at school in order to generate pro-environmental behaviour in practice, the lack of national and supranational policies on plastic waste management can hinder the positive effects of environmental awareness. We cannot forget that it is often social movements and collective change that lead to new legislation. We know that the impact of this project was not strong enough to become firmly established in the community in the long term. However, we also know that, thanks to projects like this one, the seeds are being sown for a new, healthier, more just world if we set our minds to it. We cannot forget that what happens on one side of the world can have an impact on the other. If we are concerned about environmental problems in Africa, we must pay attention to the problems and policies that concern us directly as individuals and as countries. Only by conceiving of a global world can we be consistent and responsible.

Lastly, we present some limitations and future lines of research. In the context where the project was implemented, English was the official language. However, the students' mother tongue is Kamara. This fact could have compromised the results of the research. For example, for the "thinking routine" activities, we required the support of the native teacher to translate the children's thoughts, since they expressed themselves more freely and easily in their own language. As a future line of research, it would be of interest to follow up with the school to see to what extent the results of the project have endured over time, as well as to expand it and implement it with the rest of the students.

Author Contributions: Conceptualization, J.-L.P., A.N.-B.; methodology, J.-L.P., C.S.-B.; formal analysis, M.-O.C.-H., A.N.-B.; investigation, J.-L.P., C.S.-B.; writing-original draft preparation, J.-L.P., M.-O.C.-H.; writing-review and editing, M.-O.C.-H., A.N.-B. All authors have read and agreed to the published version of the manuscript.

Funding: This research received no external funding.

Institutional Review Board Statement: The study was conducted according to the guidelines of the Declaration of Helsinki.

Informed Consent Statement: Informed consent was obtained from all subjects involved in the study.

Acknowledgments: This research would not have been possible without the collaboration of the students, teachers, and families of the public school 'Wulugu Project", "Glory Land Foundation", and the community of Larabanga, Ghana. We are also grateful for the support of the NGDO ADEPU, the Segovia Faculty of Education of the University of Valladolid, Spain, and the teaching innovation project "The Practicum in Ghana as a service-learning strategy in the initial training of professionals in education, communication, health and ecology".

Conflicts of Interest: The authors declare no conflict of interest.

\section{References}

1. Alimi, O.S.; Fadare, O.O.; Okoffo, E.D. Microplastics in African Ecosystems: Current knowledge, abundance, associated contaminants, techniques, and research needs. Sci. Total Environ. 2020, 755, 142422. [CrossRef]

2. Chico-Ortiz, N.; Mahu, E.; Crane, R.; Gordon, C.; Marchant, R. Microplastics in Ghanaian coastal lagoon sediments: Their occurrence and spatial distribution. Reg. Stud. Mar. Sci. 2020, 101509. [CrossRef]

3. Apeh, C.C. Survey of Sachet Water Waste Disposal in Liberia. J. Health Pollut. 2020, 8, 181211. [CrossRef]

4. Quartey, E.; Tosefa, H.; Danquah, K.; Obrsalova, I. Theoretical framework for plastic waste management in Ghana through extended producer responsibility: Case of sachet water waste. Int. J. Environ. Res. Public Health 2015, 12, 9907-9919. [CrossRef]

5. Our World in Data. 2010. Available online: https:// ourworldindata.org/grapher/inadequately-managed-plastic (accessed on 7 January 2021). 
6. Jambeck, J.R.; Geyer, R.; Wilcox, C.; Siegler, T.R.; Perryman, M.; Andrady, A.; Narayan, R.; Law, K.L. Plastic waste inputs from land into the ocean. Science 2015, 347, 768-771. [CrossRef] [PubMed]

7. Appiah, J.K.; Berko-Boateng, V.N.; Tagbor, T.A. Use of waste plastic materials for road construction in Ghana. Case Stud. Construct. Mater. 2017, 6, 1-7. [CrossRef]

8. Appiah-Opoku, S. Environmental impact assessment in developing countries: The case of Ghana. Environ. Impact Assess. Rev. 2001, 21, 59-71. [CrossRef]

9. Fobil, J.N.; Hogarh, J.N. The dilemmas of plastic wastes in a developing economy: Proposals for a sustainable management approach for Ghana. West Afr. J. Appl. Ecol. 2006, 10. [CrossRef]

10. Lagrange, L.; Reddy, C. Learning of environment(s) and environment(s) of learning. S. Afr. J. Environ. Educ. 2007, $24,76-81$.

11. Alegre, S. La Importancia de la Participación Ciudadana a Través de la Educación Ambiental Para la Mitigación del Cambio Climático a Nivel Local. Rev. Desarro. Local 2007, 3, 1-11. Available online: https://www.eumed.net/rev/delos/07/sia.pdf (accessed on 7 January 2021).

12. Adams, J. Qualitative Research...What's in a Name. In Workshop on Scientific Foundations of Qualitative Research; Ragin, C.C., Nagel, J., White, P., Eds.; National Science Foundation: Los Angeles, CA, USA, 2004; pp. $29-31$.

13. Simons, H. Case Study Research in Practice; Sage: Los Angeles, CA, USA, 2009; pp. 13-28.

14. Stake, R.E. The Art of Case Study Research; Sage: Thousand Oaks, CA, USA, 1995; pp. 35-49.

15. Stake, R.E. Qualitative Case Studies. In The Sage Handbook of Qualitative Research; Denzin, N.K., Lincoln, Y.S., Eds.; Sage: Thousand Oaks, CA, USA, 2011; pp. 443-467.

16. Hershberger, K.; Zembal-Saul, C.; Starr, M.L. Evidence helps the KWL get a KLEW. Sci. Child. 2006, 43, 50.

17. UNESCO. Shaping the Future We Want: Un Decade of Education for Sustainable Development. Final Report. 2014 , pp. 1-201. Available online: https://unesdoc.unesco.org/ark:/48223/pf0000230171_eng (accessed on 18 January 2021).

18. Dzerefos, C. Reviewing education for sustainable development practices in South African eco-schools. Environ. Educ. Res. 2020, 26, 1621-1635. [CrossRef]

19. Kadenyi, M.; George, K.; Marcella, M.; Kyalo, W.B. Competent governance for sustainable development in Africa: A philosophical reflection. Glob. J. Educ. Res. 2013, 1, 127-132.

20. Manteaw, O.O. Education for sustainable development in Africa: The search for pedagogical logic. Int. J. Educ. Dev. 2012, 32, 376-383. [CrossRef]

21. Matsuguma, Y.; Takada, H.; Kumata, H.; Kanke, H.; Sakurai, S.; Suzuki, T.; Weerts, S. Microplastics in sediment cores from Asia and Africa as indicators of temporal trends in plastic pollution. Arch. Environ. Contam. Toxicol. 2017, 73, 230-239. [CrossRef]

22. Ministry of Education-Republic of Ghana. Kindergarten Curriculum for Primary Schools. Accra: The Executive Secretary. September 2019. Available online: https:/ / nacca.gov.gh/wp-content/uploads/2019/06/KG-Curriculum.pdf (accessed on 10 December 2020).

23. Law, K.L.; Thompson, R.C. Microplastics in the seas. Science 2014, 345, 144-145. [CrossRef]

24. Hirai, H.; Takada, H.; Ogata, Y.; Yamashita, R.; Mizukawa, K.; Saha, M.; Kwan, C.; Moore, C.; Gray, H.; Laursen, D.; et al. Organic micropollutants in marine plastics debris from the open ocean and remote and urban beaches. Mar. Pollut. Bull. 2011, 62, 1683-1692. [CrossRef]

25. Van Cauwenberghe, L.; Vanreusel, A.; Mees, J.; Janssen, C.R. Microplastic pollution in deep-sea sediments. Environ. Pollut. 2013, 182, 495-499. [CrossRef]

26. Adu-Boahen, K.; Dadson, I.Y.; Mensah, D.K.D.; Kyeremeh, S. Mapping ecological impact of microplastics on freshwater habitat in the central region of Ghana: A case study of River Akora. GeoJournal 2020. [CrossRef]

27. Mangizvo, R.V. 'The incidence of plastic waste and their effects in Alice, South Africa'. Online J. Soc. Sci. Res. 2012, 1, 49-53.

28. Acheampong, E.A. Flooding in Accra: The Ripple Effects of Choked Drains. 5 September 2010. Available online: http: //www.ghanaweb.com/GhanaHomePage/features/Flooding-In-Accra-The-Ripple-Effects-Of-Choked-Drains-189725 (accessed on 16 January 2021).

29. Ripple, W.; Wolf, C.; Newsome, T.; Bernard, P.; Moomaw, W. World Scientists' Warning of a Climate Emergency. BioScience 2019, 70, 8-11. [CrossRef]

30. Lambert, S.; Sinclair, C.; Boxall, A. Occurrence, degradation, and effect of polymer-based materials in the environment. Rev. Environ. Contam. Toxicol. 2013, 227, 1-53. [CrossRef]

31. Lusher, A. Microplastics in the marine environment: Distribution, interactions and effects. In Marine Anthropogenic Litter; Bergmann, M., Gutow, L., Klages, M., Eds.; Springer: Cham, Switzerland, 2015; pp. 245-307.

32. GESAMP. Sources, Fate and Effects of Microplastics in the Marine Environment: A Global Assessment; International Maritime Organization: London, UK, 2015; pp. 1-93. Available online: https:/ /ec.europa.eu/environment/marine/good-environmental-status / descriptor-10/pdf/GESAMP_microplastics\%20full\%20study.pdf (accessed on 5 January 2021).

33. Andrade Frich, B. Significación ambiental y cambio climático: Una propuesta educativa de participación ciudadana para la gestión comunitaria. Rev. Rúbricas 2015, 44-49. Available online: https://repositorio.iberopuebla.mx/handle/20.500.11777/729 (accessed on 20 January 2021).

34. Kollmuss, A.; Agyeman, J. Mind the Gap: Why Do People Act Environmentally and What Are the Barriers to Pro-Environmental Behavior? Environ. Educ. Res. 2002, 8, 239-260. [CrossRef] 
35. McKenzie-Mohr, D. Fostering Sustainable Ehavior: An Introduction to Community-Based Social Marketing, 3rd ed.; New Society Publishers: Gabriola Island, BC, Canada, 2011.

36. Jensen, B.B. Knowledge, Action and Pro-Environmental Behaviour. Environ. Educ. Res. 2002, 8, 325-334. [CrossRef]

37. Pooley, J.A.; O'Connor, M. Environmental Education and Attitudes: Emotions and Beliefs Are What is Needed. Environ. Behav. 2000, 32, 711-723. [CrossRef]

38. Packalén, S. Culture and Sustainability. Corp. Soc. Responsib. Environ. Manag. 2010, 17, 118-121. [CrossRef]

39. Eernstman, N.; Wals, A. Locative Meaning-making: An Arts-based Approach to Learning for Sustainable Development. Sustainability 2013, 5, 1645-1660. [CrossRef]

40. Ingram, D. The Jukebox in the Garden: Ecocriticism and American Popular Music since 1960; Nature Culture and Literature Series; Rodopi: Amsterdam, The Netherlands, 2010; pp. 1-276.

41. Branagan, M. Environmental Education, Activism, and the Arts. Convergence 2005, 38, 33-50.

42. Galloway, K. Ecotopian Spaces: Soundscapes of Environmental Advocacy and Awareness. Soc. Altern. 2014, 33, 71-79.

43. Pedelty, M. A Song to Save the Salish Sea: Musical Performance as Environmental Activism; Indiana University Press: Bloomington, USA, 2016; pp. 1-277.

44. Banco Mundial. Informe Sobre el Desarrollo Mundial 2010: Desarrollo y Cambio Climático (Panorama General, un Nuevo Clima Para el Desarrollo; Banco Mundial: Washington, DC, USA, 2010; pp. 1-40. Available online: http://siteresources.worldbank.org/ INTWDR2010/Resources/5287678-1226014527953/Overview-Spanish.pdf (accessed on 5 January 2021).

45. Cartea, P. Crisis ambiental y globalización: Una lectura para educadores ambientales en un mundo insostenible. Trayectorias 2006, 20-21, 110-123. Available online: https:/ / www.redalyc.org/pdf/607/60715248011.pdf33--50 (accessed on 15 December 2020).

46. Lambert, M.; Sabutey, V.K. Ghana's Plastic Waste Management Problems-Aglobal Issue That Needs Local Awareness. 26 July 2016. Available online: https:/ /www.myjoyonline.com/opinion/2016/july-26th/ghanas-plastic-waste-management-problemsaglobal-issue-that-needs-local-awareness.php (accessed on 22 January 2021).

47. Jucyte, K.; Kevelaitis, K.; Renzhong, J.; Hirschpold, A.; Varona, H.P.; Debin, L. Economical and Ecological Feasibility of Plastic Recycling. 2005, pp. 4-75. Available online: https://core.ac.uk/download/pdf/12515143.pdf (accessed on 10 January 2021).

48. Yeboah, R.; Asante, E.A.; Opoku-Asare, N.A. Recycling solid waste materials to develop instructional resources for art education. Int. J. Educ. Through Art 2017, 13, 193-215. [CrossRef]

49. Antwi, M. Education, Society and Development in Ghana; Unimax Publishers Limited: Accra, Ghana, $1992 ;$ pp. 1-282.

50. Tamakloe, E.K. The nature of social studies and its curriculum implications. J. Inst. Educ. 1991, 2, 4-7.

51. Gérard, E. Être instruit, en tout cas. Représentations du fait scolaire en milieu urbain (Burkina Faso). Autrepart Bondy Paris 1999, $11,101-114$.

52. Nyarkoh, E.; Intsiful, E. An Assessment of the Impact of International Aid on Basic Education in Ghana. Am. J. Educ.Res. 2018, 6, 43-49. [CrossRef]

53. Reynés Ramón, M. Familias y sistemas educativos en África negra. Foro Educ. 2012, 10, 115-130.

54. Bortolato, M.G.; Lenti, C.A.; Morelli, R.D.; Verger, G.I. El Prototipado rápido en plástico ABS como herramienta didáctica. EGRAFIA 2008, 1, 2-4.

55. Liyakhath Ali, S.; Papaiah, M. Learning by doing: Innovative use of low cost/no cost teaching learning materials. Int. J. Hum. Soc. Sci. Invent. 2015, 4, 1-7.

56. Uyanık, O.; Çalışandemir, F.; Can-Yaşar, M.; Kandır, A. New explorations with waste materials in early childhood education. US-China Educ. Rev. 2011, A, 111-118.

57. Jasim, A. Teaching of Biological Sciences; PHI Learning Private Limited: New Delhi, Indian, 2011; pp. 1-396.

58. Kolb, D.A. Experiential Learning: Experience as the Source of Learning and Development; Pearson Education Press: Trenton, NJ, USA, 2014; pp. 1-378.

59. Reyero Sáez, M. La educación constructivista en la era digital. Rev. Tecnol. Cienc. Y Educ. 2019, 12, 111-127. Available online: https:/ / tecnologia-ciencia-educacion.com/judima/index.php/TCE/article/view/244 (accessed on 7 January 2021).

60. Hohmann, M.; Weikart, P.D. The Education of Early Children; Hisar Foundation Publication: Istanbul, Turkey, $2000 ;$ pp. 1-184.

61. da Silva Macedo, S.; Correa, S.F.; Rocha, M.M.O.; Silva, R.; Pires, V.B. Uso de material reciclado para a construção de material didático no ensino da matemática. Res. Soc. Dev. 2019, 8, 1-12.

62. Eisner, E. The Arts and the Creation of the Mind; Yale University Press: New Haven, CT, USA, 2002; pp. 1-280.

63. Eckhoff, A.; Spearman, M. Rethink, reimagine, reinvent: The Reggio Emilia approach to incorporating reclaimed materials in children's artworks. Art Educ. 2009, 62, 10-17. [CrossRef]

64. Dewey, J. Art as Experience; Capricorn Press: New York, NY, USA, 1958; pp. 1-371.

65. Alobo, J.O. Towards selection of instructional media for effective teaching and learning of English as a second language in secondary schools'. J. Niger. Engl. Stud. Assoc. 2010, 13, 106-116.

66. Ever Gold. Fuera de África, con Serge Attukwei Clottey-SF Weekly. 16 November 2018. Available online: https:/ /www.artsy. net/ever-gold/article/ever-gold-projects-africa-serge-attukwei-clottey-sf-weekly-2018 (accessed on 18 January 2021).

67. Newcombe, N.S. Picture this: Increasing math and science learning by improving spatial thinking. Am. Educ. $2010,34,29-35$.

68. Lindemann-Matthies, P. 'Loveable' mammals and 'lifeless' plants: How children's interest in common local organisms can be enhanced through observation of nature. Int. J. Sci. Educ. 2005, 27, 655-677. [CrossRef] 
69. Owusu-Sekyere, E.; Osumanu, I.K.; Abdul-Kadri, Y. An analysis of the plastic waste collection and wealth linkages in Ghana. Int. J. Curr. Res. 2013, 5, 205-209.

70. UNESCO. Educación Para Los Objetivos de Desarrollo Sostenible: Objetivos de Aprendizaje; United Nations Educational, Scientific and Cultural Organization: París, France, 2017; pp. 1-62. Available online: https://unesdoc.unesco.org/ark:/48223/pf0000252423 (accessed on 7 January 2021).

71. Velis, C.; Cook, E. Mismanagement of Plastic Waste through Open Burning in the Global South: A Systematic Review of Risks to Occupational and Public Health. 6 December 2020. Available online: https:/ / engrxiv.org/ qwy4d/ (accessed on 10 January 2021).

72. Hartmeyer, H.; Wegimont, L. (Eds.) Global Education in Europe Revisited. Strategies and Structures. Policy, Practice and Challenges; Waxmann: Münster, Germany, 2016; pp. 10-249. Available online: http://waxmann.ciando.com/img/books/extract/3830985274 _lp.pdf (accessed on 15 January 2021). 